\title{
The Joe M. Smith Collection from the Roseborough Lake Site (41BW5), Bowie County, Texas
}

Timothy K. Perttula

Heritage Research Center, Stephen F. Austin State University

Follow this and additional works at: https://scholarworks.sfasu.edu/ita

Part of the American Material Culture Commons, Archaeological Anthropology Commons, Environmental Studies Commons, Other American Studies Commons, Other Arts and Humanities Commons, Other History of Art, Architecture, and Archaeology Commons, and the United States History Commons

Tell us how this article helped you.

This Article is brought to you for free and open access by the Center for Regional Heritage Research at SFA ScholarWorks. It has been accepted for inclusion in Index of Texas Archaeology: Open Access Gray Literature from the Lone Star State by an authorized editor of SFA ScholarWorks. For more information, please contact cdsscholarworks@sfasu.edu. 
The Joe M. Smith Collection from the Roseborough Lake Site (41BW5), Bowie County, Texas

\section{Creative Commons License}

\section{(c) (1) (8)}

This work is licensed under a Creative Commons Attribution-NonCommercial 4.0 International License 


\title{
The Joe M. Smith Collection from the Roseborough Lake Site (41BW5), Bowie County, Texas
}

\author{
Timothy K. Perttula
}

\section{INTRODUCTION}

The Joe M. Smith collection is held by the Texas Archeological Research Laboratory at The University of Texas at Austin. It appears to have been given by Mr. Smith to A. T. Jackson in the early 1930s, around the time of The University of Texas excavations at the nearby Eli Moores site (41BW2). The collection is said to have come from the Rochelle Plantation, which is an earlier name for the Roseborough Lake site (41BW5) (Miroir et al. 1973:113; Gilmore 1986:2). The Roseborough Lake site is on an old meander of the Red River "that was cut off in 1872 and named Roseborough Lake" (Gilmore 1986:1). It lies a few miles west of other important Caddo sites, a few miles west of Texarkana in Bowie County (Figure 1).

The Roseborough Lake site is a large historic Caddo village occupied from the 17th century until the late 18th century, with habitation features and cemeteries (Miroir et al. 1973; Gilmore 1978). It also is the location of a Nassonite post established by the French in the 1720s, known by the Spanish as San Luis de Cadohadacho.

Investigations at the Roseborough Lake site by Miroir et al. (1973) and Gilmore (1986) recovered Historic Caddo ceramics, mainly shell-tempered, of the types Emory Punctated-Incised, McKinney Plain, Keno Trailed, Simms Engraved, Natchitoches Engraved, Womack Engraved, and Avery Engraved, along with brushed,

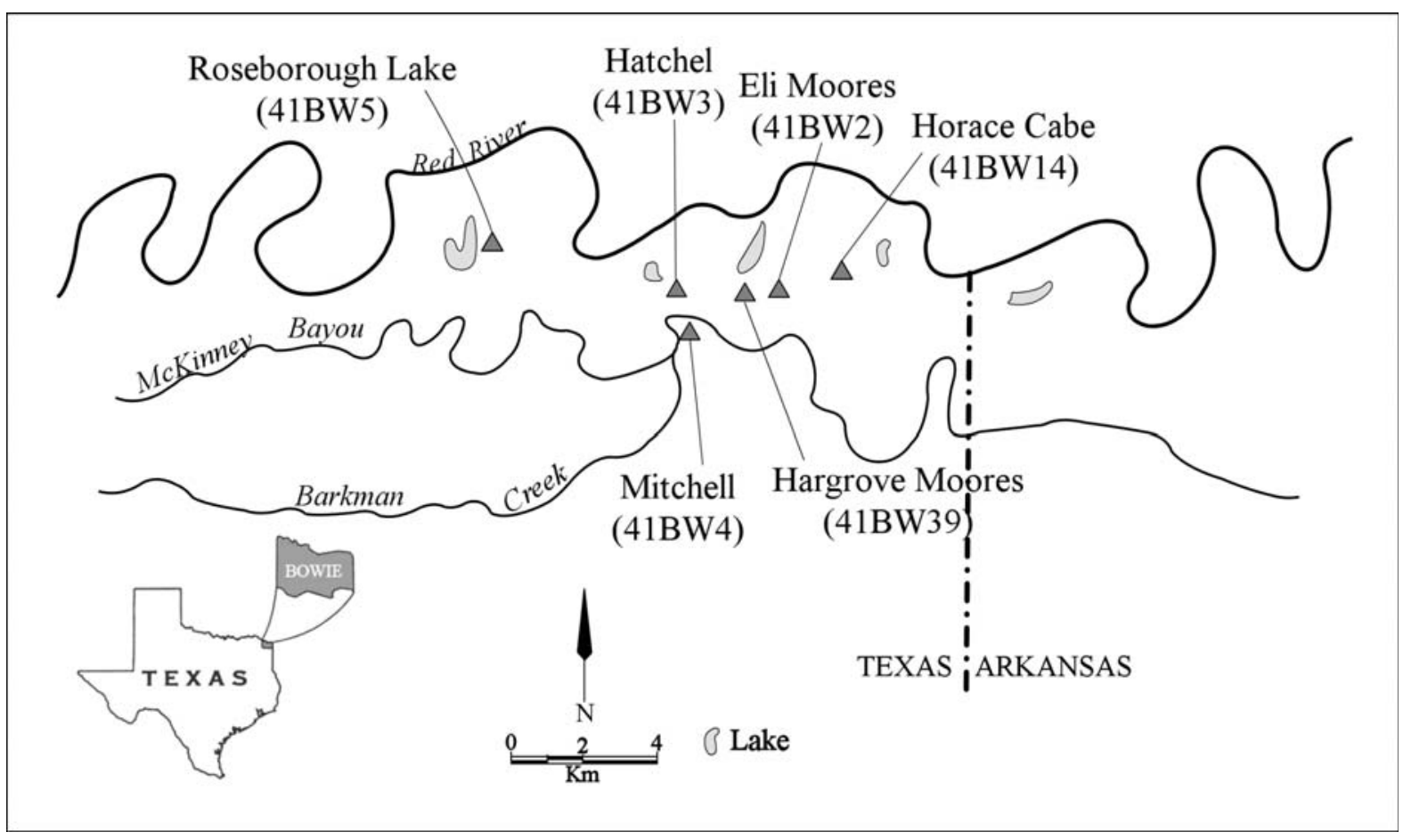

Figure 1. The Roseborough Lake site and other Caddo sites along the Red River in Bowie County, Texas. 
incised, punctated, and red-slipped body sherds and clay figurines and pipes. The chipped stone tool assemblage included Fresno and Maud arrow points, drills, large knives, many end/side scrapers, as well as a diorite celt. European trade goods are particularly abundant at the Roseborough Lake site, and they include iron axes and scrapers, iron bridle bits and knives, iron strike-a-lights, scissors, iron kettle pieces, pendants, many flintlock gun parts, gunflints, lead balls, brass rings, tinklers, bells, and rivets, brass and iron arrow points, metal buttons, green wine bottle glass and mirror glass, faience, majolica, and delft ceramics, along with many glass beads $(n=2958)$ and shell beads $(n=18)$. Substantial samples of animal bones are also present in the archaeological deposits at the site, along with carbonized maize cob fragments (Gilmore 1986:105-134).

\section{COLLECTION}

The Joe M. Smith collection from the Roseborough Lake site includes 22 Caddo ceramic sherds, a chert drill, a quartz crystal, and a conch shell bead. Presumably, all of these artifacts were collected from the surface of the site at one time or another.

Four of the sherds are plain body sherds. The remainder are decorated rim and body sherds from utility ware and fine ware vessels. One body sherd is from an Emory Punctated-Incised vessel with widely-spaced rows of tool punctations, while a roughened jar rim is from a McKinney Plain vessel with a direct rim and a rounded lip. Four brushed body sherds are from Karnack Brushed-Incised vessels; two of these are shell-tempered. There are five body sherds with incised decorative elements: three have parallel incised lines and the other two diagonal opposed elements that may be from unspecified varieties of Foster-Trailed Incised (Figure 2a-b).

There are three Keno Trailed bowl sherds in the collection. They have multiple curvilinear trailed lines (see Figure 2c) on the rim and body. One lower rim sherd is from a Simms Engraved carinated bowl. The rim in profile is set almost at a right angle, suggesting it is from a hub-cap style form (see Suhm and Jelks 1962:Plate 71b-c, f). The lower rim sherd is decorated with at least two horizontal lines with small excised triangular-shaped tick marks. Another engraved rim sherd in the Joe M. Smith collection has a single horizontal line under the rounded lip, as well as a series of diagonal engraved lines; the sherd is from a redslipped carinated bowl.

The last two engraved fine ware sherds in the Joe M. Smith collection are body sherds from two different Natchitoches Engraved vessels (see Figure 2d-e), likely carinated bowls. The first has a ticked curvilinear scroll line and a scroll fill zone with hatched brackets (see Figure 2d). The second Natchitoches Engraved sherd has a ticked slanting scroll line between narrow zones filled with cross-hatched lines (see Figure 2e).

The drill is on a bifacially-flaked non-cortical flake. The flake is from a gray chert pebble or cobble that was likely obtained in nearby Red River gravels. A clear $60.1 \mathrm{~mm}$ long and $19.1 \mathrm{~mm}$ wide quartz crystal is in the collection; it has been flaked along one edge. Similar quartz crystals have been recovered in platform mound archaeological deposits at the nearby Hatchel site (41BW3) (Perttula 2014:Figure 34a-b).

The polished conch shell bead is $32.2 \mathrm{~mm}$ in length and $11.2 \mathrm{~mm}$ in width. The drilled hole is $4.0 \mathrm{~mm}$ in diameter.

\section{SUMMARY}

Although this small collection of artifacts from the Roseborough Lake site does not contain any historic European trade goods, the combination of decorated fine ware ceramic sherds from Natchitoches Engraved, Keno Trailed, and Simms Engraved vessels is consistent with an Historic Caddo occupation that dates from the ca. late 17th century to at least the mid-18th century. The collection likely came from Area A at the site (see Miroir et al. 1973:114 and Figure 2), the main village of the Caddo in historic times. 


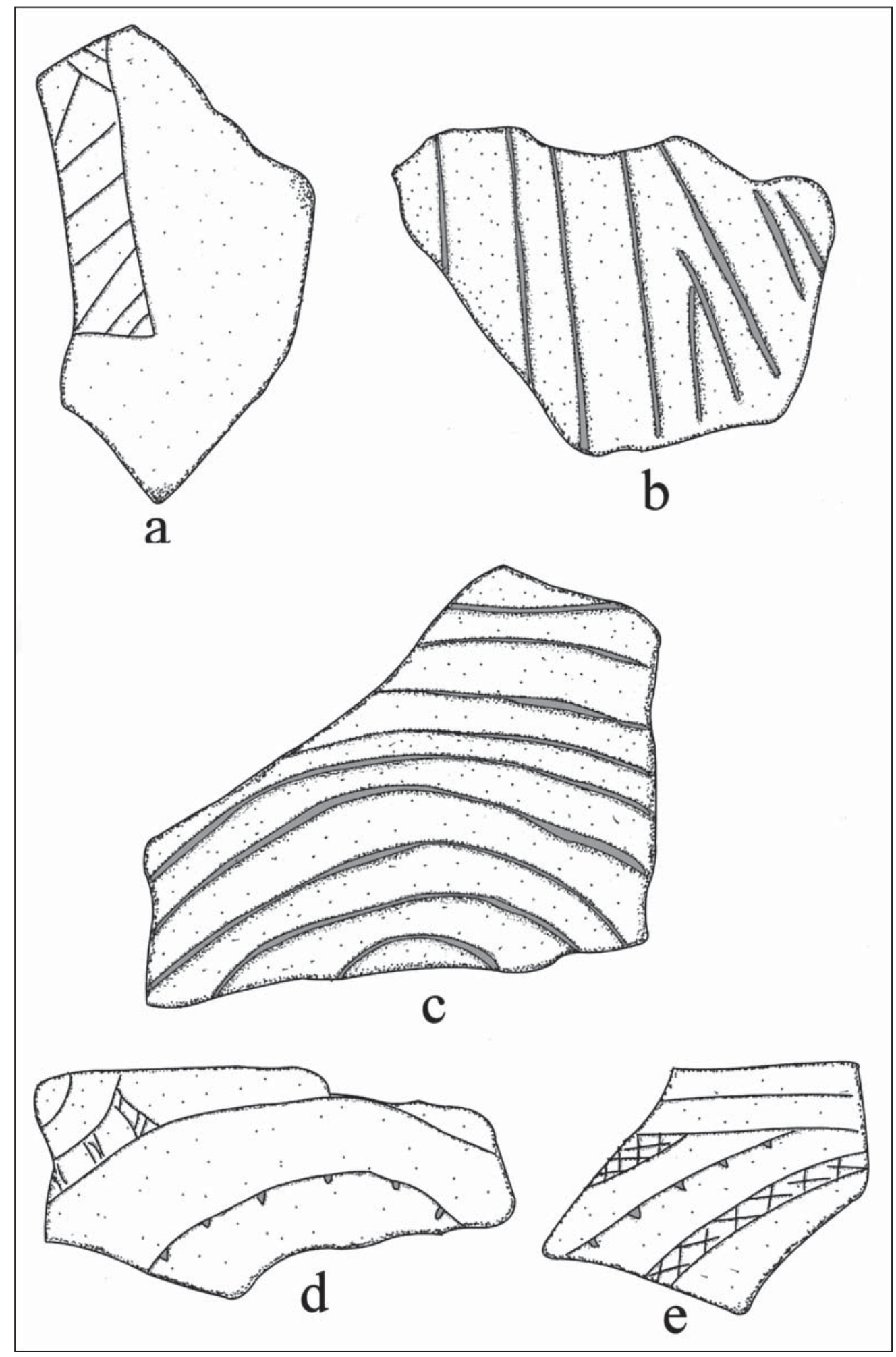

Figure 2. Decorative elements on sherds from the Joe M. Smith collection from the Roseborough Lake site: a-b, incised body elements (cf. Foster Trailed-Incised); c, Keno Trailed; d-e, Natchitoches Engraved. 


\section{ACKNOWLEDGEMENTS}

Lance Trask prepared the figures for this article. Laura Nightengale of the Texas Archeological Research Laboratory at The University of Texas at Austin facilitated the study of this collection.

\section{REFERENCES CITED}

Gilmore, K.

1986 French-Indian Interaction at an Early Eighteenth Century Post: The Roseborough Lake Site, Bowie County, Texas. Contributions in Archaeology 3. Institute of Applied Sciences, North Texas State University, Denton.

Miroir, M. E., R. K. Harris, J. C. Blaine, and J. McVay

1973 Bernard de la Harpe and the Nassonite Post. Bulletin of the Texas Archeological Society 44:113-167.

Perttula, T. K.

2014 Archaeological Studies of the Hatchel Site (41BW3) on the Red River in Bowie County, Texas. Special Publication No. 23. Friends of Northeast Texas Archaeology, Pittsburg and Austin.

Suhm, D. A. and E. B. Jelks (editors)

1962 Handbook of Texas Archeology: Type Descriptions. Special Publication No. 1, Texas Archeological Society and Bulletin No. 4, Texas Memorial Museum, San Antonio. 